\title{
Impact of Nutrient Management Practices on the Status and Quality of Soil Humus in Newly Developed Terraced Land
}

\author{
Manoj Dutta* and B. S. Chauhan ${ }^{1}$ \\ Dept. of Soil and Water Conservation, SASRD, Nagaland University, Medziphema Campus, Medziphema, Nagaland \\ (797 106), India \\ ${ }^{1}$ Presently Dept. of Environmental Science, Patkai Christian College, Chumukedima, Patkai, Nagaland (797 103), India
}

\section{Article History}

Manuscript No. AR678

Received in $11^{\text {th }}$ March, 2014

Received in revised form $5^{\text {th }}$ September, 2014

Accepted in final form $4^{\text {th }}$ January, 2015

\section{Correspondence to}

"E-mail: manojdutta1997@yahoo.com

\section{Keywords}

$\mathrm{C}: \mathrm{N}: \mathrm{P}$, soil humus, humus quality, terraced land

\begin{abstract}
An experiment was conducted in the experimental farm at School of Agricultural Sciences and Rural Development, Medziphema, Nagaland to evaluate the impact of different nutrient management practices on content and quality of soil humus in a newly developed terraced land. Twelve treatments involving N, P and K (NPK) fertilizers, farmyard manure (FYM), poultry litter, forest litter, Azospirillum and Zn either alone or in combinations were applied continuously for two years. On an average, fulvic $\mathrm{C}$, humic $\mathrm{C}$ and humin $\mathrm{C}$ was $48.1,21.1$ and $30.8 \%$ of humus $\mathrm{C}$, respectively. The fulvic $\mathrm{C}$ was the largest fraction of humus $\mathrm{C}$ in soil followed by humin $\mathrm{C}$ and humic $\mathrm{C}$. With the present rate of accumulation of humus $\mathrm{C}$, the soil under different treatments showing build up of humus $\mathrm{C}$ would take 3.5 to 66.0 years with an average of 23.2 years to reach its original $\mathrm{C}$ content present before terracing. Among the fractions, fulvic $\mathrm{N}$ was the largest fraction of humus $\mathrm{N}$ in all the treatments followed by humic $\mathrm{N}$ or humin $\mathrm{N}$. On an average, fulvic $\mathrm{N}$, humic $\mathrm{N}$ and humin $\mathrm{N}$ was 58.8 , 21.2 and $20.0 \%$ of humus $\mathrm{N}$, respectively. After two years, the rate of build up of humus $\mathrm{N}$ in various nutrient management practices was 18.3 to $76.4 \mathrm{~kg} \mathrm{~N}^{-1} \mathrm{yr}^{-1}$ with an average of $44.5 \mathrm{~kg} \mathrm{~N} \mathrm{ha}^{-1} \mathrm{yr}^{-1}$. Among the fractions, fulvic $\mathrm{P}$ was the largest fraction of the humus $\mathrm{P}$ followed by humic $\mathrm{P}$ and humin $\mathrm{P}$ in all the treatments. On an average, fulvic $P$, humic $P$ and humin $P$ constituted 65.4, 20.5 and $14.1 \%$ of humus $\mathrm{P}$, respectively. The lowest $\mathrm{C}: \mathrm{N}: \mathrm{P}$ ratio of soil humus, fulvic acid and humic acid was in NPK+Poultry litter treatment. The average C:N:P ratios of soil humus, fulvic acid, humic acid and humin was estimated to be 133.1:10.8:1, 98.2:9.8:1, 138.0:11.4:1 and 281.8:15.0:1, respectively.
\end{abstract}

\section{Introduction}

Soil fertility development of the resultant surface soil after terracing could be achieved through the addition of manures, fertilizers, bio-fertilizers, organic residues and other amendments either alone or in combinations. The addition of $\mathrm{N}, \mathrm{P}$ and $\mathrm{K}$ fertilizers with organic sources would increase the availability of these nutrients to growing plants and favour accumulation of organic matter in surface soil besides improving soil properties. The addition of NPK fertilizers with or without organic residues or manures on newly developed terraced land would affect the levels and quality of soil humus with respect to plant nutrients accumulating with it. Soil organic matter as the repository of these nutrients and most of the micronutrients essential for plant growth would affects their availability to the plants. All the management practices that bring about favourable changes in important physical properties of soil, status and availability of plant nutrients and affect the quantity and quality of soil humus with respect to $\mathrm{N}$ and $\mathrm{P}$ accumulating in soil are of immense practical significance in crop production on terraced land. The nutrient management practices that could encourage accumulation of soil organic matter of narrow $\mathrm{C}: \mathrm{N}$ and $\mathrm{C}: \mathrm{P}$ ratios are expected to conserve soil fertility. As the information on the subject is scanty, the investigation was carried out to evaluate the impact of nutrient management practices on status and quality of soil humus on terraced land.

\section{Materials and Methods}

A hill slope (22\%) was bench terraced in 2001 at the institutional farm. Three numbers of bench terraces, $26.0 \mathrm{~m}$ 
long and $3.5 \mathrm{~m}$ wide were constructed manually. An experiment on these terraces was conducted in 2001 and 2002. The soil data collected in Kharif 2002 after harvest of upland rice are reported here. The experiment was laid out in Randomized Block Design with twelve treatments and replicated thrice in plots of $2.0 \times 3.0 \mathrm{~m}^{2}$ size separated by a bund of $15 \mathrm{~cm}$. A border of $25 \mathrm{~cm}$ along the riser was left. During each year, the plots were manually prepared to ensure good seedbed. The recommended dose of $60 \mathrm{~kg} \mathrm{~N}, 60 \mathrm{~kg} \mathrm{P}_{2} \mathrm{O}_{5}$ and $40 \mathrm{~kg}$ $\mathrm{K}_{2} \mathrm{O} \mathrm{ha}^{-1}$ for rice was applied. The farmyard manure (FYM), poultry litter and forest litter was applied @ $10.0 \mathrm{t} \mathrm{ha}^{-1}, 3.3 \mathrm{t}$ $\mathrm{ha}^{-1}$ and $5.0 \mathrm{t} \mathrm{ha}^{-1}$, respectively. For $1 / 2 \mathrm{~N}\left(30 \mathrm{~kg} \mathrm{ha}^{-1}\right)$ through FYM, poultry litter and forest litter, calculated amounts of these organic sources containing $0.5,1.5$ and $0.1 \% \mathrm{~N}$, respectively were applied (6.0, 2.0 and $30.0 \mathrm{tha}^{-1}$, respectively) to the soil. Zinc (Zn)was applied @ $10 \mathrm{~kg} \mathrm{ha}^{-1}$ in the form of $\mathrm{ZnSO}_{4} .7 \mathrm{H}_{2} \mathrm{O}$ as basal dose. Azospirillum was used as seed treatment @ 20 $\mathrm{g} \mathrm{kg}^{-1}$ of seed. For forest litter burned $+1 / 2$ FYM treatment that resembles farmers' practice in Nagaland, forest litter @ $5.0 \mathrm{t}$ $\mathrm{ha}^{-1}$ was evenly spread on the soil surface and burned. The ash was incorporated thoroughly in the soil. The FYM, $1 / 2$ FYM, poultry litter and forest litter were applied one month before sowing and mixed well in the soil. Upland rice variety Teke (landrace) was sown with a spacing of $20 \mathrm{~cm}$ row to row using a seed rate of $75 \mathrm{~kg} \mathrm{ha}^{-1}$ each year.

Soil samples collected after the harvest of $2^{\text {nd }}$ year rice were air dried, prepared and analyzed for various constituents. Soil organic $\mathrm{C}$ was fractionated into fulvic $\mathrm{C}$, humic $\mathrm{C}$ and humin C by the method of Anderson and Schoenau (1993). The organic carbon content in soil, fulvic and humic fractions was determined by Walkley and Black method as described by Jackson (1973). Soil organic carbon content was taken as humus $\mathrm{C}$. The organic $\mathrm{N}$ taken as humus $\mathrm{N}$ was determined by using sodium carbonate and concentrated sulphuric acid as described by Chopra and Kanwar (1991). The N in fulvic and humic fractions was determined by modified kjeldahl digestion and distillation method (Jackson, 1973). The organic $\mathrm{P}$ was taken as humus P. The P in Humus, fulvic and humic fractions was estimated colorimetrically using the procedure of Dickman and Bray as described by Jackson (1973). The difference between humus $\mathrm{C}, \mathrm{N}$ and $\mathrm{P}$ content and $\mathrm{C}, \mathrm{N}$ and $\mathrm{P}$ in both fulvic and humic fractions was taken as humin $\mathrm{C}, \mathrm{N}$ and $\mathrm{P}$, respectively. The statistical analysis of the data was done as per procedure outlined by Gomez and Gomez (1984).

\section{Results and Discussion}

\subsection{Humus $C$, fulvic $C$, humic $C$ and humin $C$ content in soil}

The humus $\mathrm{C}$ in the soils ranged from 17400 to 21200 $\mathrm{mg} \mathrm{kg}{ }^{-1}$ with an average of $18500 \mathrm{mg} \mathrm{kg}^{-1}$ and showed a significant increase in all the treatments except in $1 / 2 \mathrm{~N}+\mathrm{PK}$, $\mathrm{NPK}, 1 / 2 \mathrm{~N}+\mathrm{PK}+$ Azospirillum and Forest litter burned $+1 / 2$ FYM over control (Table 1). The highest humuc $\mathrm{C}$ recorded in $1 / 2 \mathrm{~N}+\mathrm{PK}+1 / 2 \mathrm{~N}$ Forest litter showed a significant build up over rest of the treatments. The humus $\mathrm{C}$ in NPK+FYM, $\mathrm{NPK}+\mathrm{FYM}+\mathrm{Zn}, \mathrm{NPK}+$ Poultry litter, NPK + Forest litter and $1 / 2 \mathrm{~N}+\mathrm{PK}+1 / 2 \mathrm{~N}$ FYM was significantly higher than NPK. The increase in humus $\mathrm{C}$ over control in different treatments ranged from 1.2 to $21.8 \%$ with an average of $6.9 \%$. Similar results were also observed by Chauhan and Humtsoe (2005) who reported 8.4 and $7.1 \%$ increase in humus $\mathrm{C}$ in Alder litter incorporated and FYM+NPK treatments over control, respectively. The humus $\mathrm{C}$ in NPK+FYM+Zn, NPK+FYM and NPK+Forest litter was 9.0, 8.4 and $4.5 \%$ higher over NPK, respectively. Similar increases in organic $\mathrm{C}$ content in soil on addition of organic sources have been reported by earlier workers (Yaduvanshi et

\begin{tabular}{|c|c|c|c|c|}
\hline Treatment No. and particulars & Humus C $\left(\mathrm{mg} \mathrm{kg}^{-1}\right)$ & Fulvic $\mathrm{C}\left(\mathrm{mg} \mathrm{kg}^{-1}\right)$ & Humic $\mathrm{C}\left(\mathrm{mg} \mathrm{kg}^{-1}\right)$ & Humin $\mathrm{C}\left(\mathrm{mg} \mathrm{kg}^{-1}\right)$ \\
\hline Control & 17400 & 8200 & 3700 & 5500 \\
\hline $1 / 2 \mathrm{~N}+\mathrm{PK}$ & 17700 & 8400 & 3800 & 5500 \\
\hline NPK & 17800 & 8500 & 3800 & 5500 \\
\hline $\mathrm{NPK}+\mathrm{FYM}$ & 19300 & 9400 & 4100 & 5800 \\
\hline $1 / 2 \mathrm{~N}+\mathrm{PK}+1 / 2 \mathrm{~N}$ FYM & 18700 & 9000 & 4000 & 5700 \\
\hline NPK+Poultry litter & 18400 & 8900 & 3900 & 5600 \\
\hline $1 / 2 \mathrm{~N}+\mathrm{PK}+1 / 2 \mathrm{~N}$ Poultry litter & 18200 & 8800 & 3800 & 5600 \\
\hline TNPK+Forest litter & 18600 & 9200 & 3800 & 5600 \\
\hline $1 / 2 \mathrm{~N}+\mathrm{PK}+1 / 2 \mathrm{~N}$ Forest litter & 21200 & 10600 & 4400 & 6200 \\
\hline $1 / 2 \mathrm{~N}+\mathrm{PK}+$ Azospirillum & 17700 & 8500 & 3700 & 5500 \\
\hline $\mathrm{NPK}+\mathrm{FYM}+\mathrm{Zn}$ & 19400 & 9400 & 4100 & 5900 \\
\hline Forest litter burned $+1 / 2$ FYM & 17600 & 8300 & 3700 & 5600 \\
\hline $\mathrm{SEm} \pm$ & 164.1 & 160.4 & 67.7 & 54.1 \\
\hline $\mathrm{CD}(p=0.05)$ & 481.6 & 470.5 & 198.6 & 158.7 \\
\hline
\end{tabular}


al., 2013; Gathala et al., 2007; Laxminarayana and Patiram, 2006). Treatments receiving $1 / 2 \mathrm{~N}$ from fertilizer and $1 / 2 \mathrm{~N}$ from forest litter or FYM caused a significant increase of $16.0 \%$ and $5.1 \%$ humus $\mathrm{C}$, respectively over NPK. The significant increase in humus $\mathrm{C}$ in integrated treatments combining inorganic fertilizers either with forest litter or with FYM may be because of the combine effect of the amount of the organic residues $\mathrm{C}$ added and its nutrient content, plant residue $\mathrm{C}$ return to the soil and efficiency of microbial population in utilizing added organic $\mathrm{C}$. The fact that humus $\mathrm{C}$ accumulated in soil with time in all treatments where organic sources were added pointed out that the process of attaining equilibrium has set in the system. With the present rate of accumulation of humus $\mathrm{C}$ in soil over control, the soil under different treatments showing build up of humus $C$ would take $3.5(1 / 2 \mathrm{~N}+\mathrm{PK}+1 / 2 \mathrm{~N}$ Forest litter) to 66.0 years (Forest litter burned $+1 / 2$ FYM) with an average of 23.2 years to reach its original C content $\left(24000 \mathrm{mg} \mathrm{kg}^{-1}\right)$ present before terracing.

The fulvic $\mathrm{C}$ in different treatments varied from 8200 to 10600 $\mathrm{mg} \mathrm{kg}{ }^{-1}$ with an average of $8900 \mathrm{mg} \mathrm{kg}^{-1}$ (Table 1) and showed a significant increase in all the treatments except in $1 / 2 \mathrm{~N}+\mathrm{PK}$, NPK, $1 / 2 \mathrm{~N}+\mathrm{PK}+$ Azospirillum and Forest litter burned $+1 / 2 \mathrm{FYM}$ over control. The fulvic $\mathrm{C}$ in NPK+FYM, NPK+FYM+Zn, $\mathrm{NPK}+$ Forest litter, $1 / 2 \mathrm{~N}+\mathrm{PK}+1 / 2 \mathrm{~N}$ FYM and $1 / 2 \mathrm{~N}+\mathrm{PK}+1 / 2 \mathrm{~N}$ Forest litter treatments increased significantly over NPK. The increase in fulvic $\mathrm{C}$ in $\mathrm{NPK}+\mathrm{FYM}+\mathrm{Zn}, \mathrm{NPK}+\mathrm{FYM}$ and NPK+Forest litter treatments over NPK was 10.6, 10.6 and $8.2 \%$ higher, respectively. The build up of fulvic $\mathrm{C}$ in $1 / 2 \mathrm{~N}+\mathrm{PK}+1 / 2 \mathrm{~N}$ Forest litter and $1 / 2 \mathrm{~N}+\mathrm{PK}+1 / 2 \mathrm{~N}$ FYM was 24.7 and $5.9 \%$, respectively as compared with NPK. Gathala et al. (2007) also recorded a significant increase in fulvic $\mathrm{C}$, humic $\mathrm{C}$ and humin $\mathrm{C}$ with the integrated use of FYM and chemical fertilizer.

The humic $\mathrm{C}$ in the soils ranged from 3700 to $4400 \mathrm{mg} \mathrm{kg}^{-1}$ with an average of $3900 \mathrm{mg} \mathrm{kg}^{-1}$ (Table 1). The humic $\mathrm{C}$ showed a significant increase in $1 / 2 \mathrm{~N}+\mathrm{PK}+1 / 2 \mathrm{~N}$ Forest litter, NPK+FYM, $\mathrm{NPK}+\mathrm{FYM}+\mathrm{Zn}, 1 / 2 \mathrm{~N}+\mathrm{PK}+1 / 2 \mathrm{~N}$ FYM and NPK+Poultry litter treatments over control. The humic $\mathrm{C}$ in NPK+FYM, $\mathrm{NPK}+\mathrm{FYM}+\mathrm{Zn}, 1 / 2 \mathrm{~N}+\mathrm{PK}+1 / 2 \mathrm{~N} F Y M$ and $1 / 2 \mathrm{~N}+\mathrm{PK}+1 / 2 \mathrm{~N}$ Forest litter was significantly higher than NPK. The increase in humic $\mathrm{C}$ over control in different treatments ranged from 0.0 to $18.9 \%$ with an average of $5.9 \%$. The build up of humic $\mathrm{C}$ in $\mathrm{NPK}+\mathrm{FYM}+\mathrm{Zn}$ and NPK+FYM treatments over NPK $7.9 \%$. The significantly higher build up of humic in $1 / 2 \mathrm{~N}+\mathrm{PK}+1 / 2 \mathrm{~N}$ Forest litter 15.8\% higher over NPK.

The humin C in the soils varied from 5500 to $6200 \mathrm{mg} \mathrm{kg}^{-1}$ with an average of $5700 \mathrm{mg} \mathrm{kg}^{-1}$ (Table 1) and showed a significant increase in $\mathrm{NPK}+\mathrm{FYM}, \mathrm{NPK}+\mathrm{FYM}+\mathrm{Zn}, 1 / 2 \mathrm{~N}+\mathrm{PK}+1 / 2 \mathrm{~N}$ FYM and $1 / 2 \mathrm{~N}+\mathrm{PK}+1 / 2 \mathrm{~N}$ Forest litter treatments as compared to control and NPK. The increase in humin C in different treatments over control varied from 0.0 to $12.3 \%$ with an average of $3.3 \%$. The increase in humin $\mathrm{C}$ in NPK+FYM, $\mathrm{NPK}+\mathrm{FYM}+\mathrm{Zn}$ and $1 / 2 \mathrm{~N}+\mathrm{PK}+1 / 2 \mathrm{~N}+\mathrm{F}$ orest litter over NPK was $5.5,7.3$ and $12.7 \%$, respectively.

On an average, fulvic $\mathrm{C}$, humic $\mathrm{C}$ and humin $\mathrm{C}$ was 48.1, 21.1 and $30.8 \%$ of humus $\mathrm{C}$, respectively. The data established that fulvic $\mathrm{C}$ on an average, was the largest fraction of humus $\mathrm{C}$ in soil followed by humin $\mathrm{C}$ and humic $\mathrm{C}$. These findings are in accordance with those reported by Chauhan and Humtsoe (2005). Accumulation of organic matter in soil is the result of the formation of biomass and their metabolites. The organic residues when added to soil are decomposed and utilized by soil microorganisms for energy and growth. Microbial population utilizes added organic $\mathrm{C}$ with an efficiency of about $60 \%$ and thus $40 \%$ of added organic $\mathrm{C}$ becomes part of soil humus and its fractions resulting an increase in soil humus $\mathrm{C}$ and its fractions.

\subsection{Humus $N$, fulvic $N$, humic $N$ and humin $N$ content in soil}

The humus $\mathrm{N}$ varied from 1469.2 to $1537.4 \mathrm{mg} \mathrm{kg}^{-1}$ with an average of $1505.6 \mathrm{~m} \mathrm{k} \mathrm{k}^{-1}$ (Table 2) and increased significantly in all the treatments except in $1 / 2 \mathrm{~N}+\mathrm{PK}, 1 / 2 \mathrm{~N}+\mathrm{PK}+$ Azospirillum and Forest litter burned $+1 / 2$ FYM over control (Table 2). The humus $\mathrm{N}$ in NPK+Poultry litter, $\mathrm{NPK}+\mathrm{FYM}+\mathrm{Zn}$ and NPK+FYM was significantly higher than NPK. The increase in humus $\mathrm{N}$ over control in different treatments varied from 36.5 to $152.8 \mathrm{~kg} \mathrm{ha}^{-1}$ with an average of $88.9 \mathrm{~kg} \mathrm{ha}^{-1}$. After two years, the rate of build up of humus $\mathrm{N}$ in various nutrient management practices was estimated to be 18.3 to $76.4 \mathrm{~kg} \mathrm{~N}$ $\mathrm{ha}^{-1} \mathrm{yr}^{-1}$ with an average of $44.5 \mathrm{~kg} \mathrm{~N} \mathrm{ha}^{-1} \mathrm{yr}^{-1}$. The significant increase in humus $\mathrm{N}$ content in NPK + Poultry litter, NPK+FYM and NPK+FYM+Zn treatments over NPK might be due to the variation in $\mathrm{N}$ content in these organic residues and its influence on the rate of decomposition and synthesis of microbial metabolites and their $\mathrm{C}: \mathrm{N}$ ratio, combine effect of which would result variation in the cumulative build up of organic $\mathrm{N}$ in these treatments. Sihag et al. (2005) also found positive effect on the build up of organic $\mathrm{N}$ with the application of FYM along with inorganic fertilizers.

The fulvic $\mathrm{N}$ content in the soil ranged from 840.5 to 926.5 $\mathrm{mg} \mathrm{kg}{ }^{-1}$ with an average of $886.2 \mathrm{mg} \mathrm{kg}^{-1}$ (Table 2) and showed a significant increase in all the treatments except in Forest litter burned $+1 / 2$ FYM over control. The highest fulvic $\mathrm{N}$ was recorded in NPK+Poultry litter treatment. The fulvic $\mathrm{N}$ in $\mathrm{NPK}+$ Poultry litter, $\mathrm{NPK}+\mathrm{FYM}$ and $\mathrm{NPK}+\mathrm{FYM}+\mathrm{Zn}$ showed a significant increase over NPK. Substituting $1 / 2 \mathrm{~N}$ through FYM or poultry litter also brought about a significant increase in fulvic $\mathrm{N}$ over NPK. The increase in fulvic $\mathrm{N}$ in different treatments over control ranged from 2.8 to $10.2 \%$ with an average of $5.9 \%$. The significant increase in fulvic $\mathrm{N}$ in NPK+FYM, NPK+FYM+Zn, NPK+Poultry litter, $1 / 2 \mathrm{~N}+\mathrm{PK}+1 / 2 \mathrm{~N}$ FYM and $1 / 2 \mathrm{~N}+\mathrm{PK}+1 / 2 \mathrm{~N}$ Poultry litter over NPK 
was $4.5,4.3,6.1,3.1$ and $2.9 \%$, respectively. The fulvic $\mathrm{N}$ in different treatments constituted 57.2 to $60.3 \%$ of humus $\mathrm{N}$ content with an average of $58.8 \%$.

The humic $\mathrm{N}$ in the soil varied from 302.8 to $338.7 \mathrm{mg} \mathrm{kg}^{-1}$ with an average of $318.5 \mathrm{mg} \mathrm{kg}^{-1}$ (Table 2) and showed a significant increase in all the treatments except in $1 / 2 \mathrm{~N}+\mathrm{PK}$, $1 / 2 \mathrm{~N}+\mathrm{PK}+$ Azospirillum, NPK, Forest litter burned $+1 / 2$ FYM and NPK + Forest litter over control. The highest humic $\mathrm{N}$ was recorded in $1 / 2 \mathrm{~N}+\mathrm{PK}+1 / 2 \mathrm{~N}$ Forest litter treatment. The Humic $\mathrm{N}$ in $\mathrm{NPK}+\mathrm{FYM}, \mathrm{NPK}+\mathrm{FYM}+\mathrm{Zn}$ and $1 / 2 \mathrm{~N}+\mathrm{PK}+1 / 2 \mathrm{~N}$ Forest litter increased significantly over NPK. The increase in humic $\mathrm{N}$ in different treatments over control varied from 0.0 to $11.6 \%$ with an average of $5.5 \%$. The significant build up in humic $\mathrm{N}$ in NPK + FYM, $\mathrm{NPK}+\mathrm{FYM}+\mathrm{Zn}$ and $1 / 2 \mathrm{~N}+\mathrm{PK}+1 / 2 \mathrm{~N}$ Forest litter over NPK was 7.1, 7.5 and 8.0\%, respectively. The humic N in different treatments represented 20.4 to $22.5 \%$ of humus $\mathrm{N}$ content with an average of $21.2 \%$.

The humin $\mathrm{N}$ in the soil ranged from 278.1 to $325.3 \mathrm{mg} \mathrm{kg}^{-1}$ with an average of $300.7 \mathrm{mg} \mathrm{kg}^{-1}$ (Table 2) and showed a significant decrease in all the treatments except in $1 / 2 \mathrm{~N}+\mathrm{PK}$, NPK, NPK + Forest litter and Forest litter burned $+1 / 2$ FYM over control. The humin $\mathrm{N}$ in NPK+FYM, NPK+FYM+Zn and $\mathrm{NPK}+$ Poultry litter was significantly lower than NPK. The humin $\mathrm{N}$ in $1 / 2 \mathrm{~N}+\mathrm{PK}+1 / 2 \mathrm{~N}$ FYM, $1 / 2 \mathrm{~N}+\mathrm{PK}+1 / 2 \mathrm{~N}$ Poultry litter and $1 / 2 \mathrm{~N}+\mathrm{PK}+1 / 2 \mathrm{~N}$ Forest litter also showed a significant decrease over NPK. The decrease in humin N in different treatments over control ranged from 12.1 to $14.5 \%$ with an average of $8.3 \%$. The significant decrease in humin $\mathrm{N}$ in NPK+FYM, $\mathrm{NPK}+\mathrm{FYM}+\mathrm{Zn}$ and NPK+Poultry litter as compared with NPK was $9.7,9.1$ and $10.1 \%$, respectively. The significant decrease in humin $\mathrm{N}$ in $1 / 2 \mathrm{~N}+\mathrm{PK}+1 / 2 \mathrm{~N}$ FYM, $1 / 2 \mathrm{~N}+\mathrm{PK}+1 / 2 \mathrm{~N}$ Poultry litter and $1 / 2 \mathrm{~N}+\mathrm{PK}+1 / 2 \mathrm{~N}$ Forest litter over NPK was
$10.7,8.8$ and $12.1 \%$, respectively. The humin $\mathrm{N}$ in different treatments constituted 18.4 to $22.1 \%$ of humus $\mathrm{N}$ with an average of $20.0 \%$.

On an average, fulvic $\mathrm{N}$, humic $\mathrm{N}$ and humin $\mathrm{N}$ was 58.8 , 21.2 and $20.0 \%$ of humus $\mathrm{N}$, respectively. These results are in conformity to the observations made by Belho and Chauhan (2013) who reported that on an average fulvic, humic and humin fractions constituted 57.2, 26.1 and $16.7 \%$ of humus $\mathrm{N}$, respectively.

\subsection{Humus $P$, fulvic $P$, humic $P$ and humin $P$ content in soil}

The humus $\mathrm{P}$ content in the soil varied from 126.9 to 152.3 $\mathrm{mg} \mathrm{kg}^{-1}$ with an average of $139.2 \mathrm{mg} \mathrm{kg}^{-}$(Table 3) and increased significantly in all the treatments except in $1 / 2 \mathrm{~N}+\mathrm{PK}$ and Forest litter burned $+1 / 2$ FYM over control. The highest humus $\mathrm{P}$ was recorded in NPK+Poultry litter followed by $1 / 2 \mathrm{~N}+\mathrm{PK}+1 / 2 \mathrm{~N}$ Poultry litter and the lowest in control. The humus $\mathrm{P}$ in NPK+FYM, NPK+Poultry litter, NPK+FYM+Zn and $1 / 2 \mathrm{~N}+\mathrm{PK}+1 / 2 \mathrm{~N}$ Poultry litter showed a significant increase over NPK. The build up of humus $\mathrm{P}$ in different nutrient management practices over control ranged from 7.2 to $56.9 \mathrm{~kg}$ $\mathrm{ha}^{-1}$ with an average of $30.0 \mathrm{~kg} \mathrm{ha}^{-1}$, respectively. Higher build up of humus $\mathrm{P}$ in NPK+Poultry litter, $1 / 2 \mathrm{~N}+\mathrm{PK}+1 / 2 \mathrm{~N}$ Poultry litter, NPK + FYM and NPK + FYM $+Z n$ over NPK could be due to higher levels of $\mathrm{P}$ added through poultry litter or FYM as well as variation in microbial activity and nature of microbial metabolites.

Among the fractions, fulvic $\mathrm{P}$ was the largest fraction of the humus $\mathrm{P}$ followed by humic $\mathrm{P}$ and humin $\mathrm{P}$ in all the treatments. The fulvic $\mathrm{P}$ content in the soil varied from 81.5 to $101.3 \mathrm{mg} \mathrm{kg}^{-1}$ with an average of $91.1 \mathrm{mg} \mathrm{kg}^{-1}$ (Table 3) and showed a significant increase in all the treatments except in $1 / 2 \mathrm{~N}+\mathrm{PK}$ and Forest litter burned $+1 / 2$ FYM over control.

\begin{tabular}{|c|c|c|c|c|}
\hline Treatments & Humus $\mathrm{N}\left(\mathrm{mg} \mathrm{kg}^{-1}\right)$ & Fulvic N $\left(\mathrm{mg} \mathrm{kg}^{-1}\right)$ & Humic N $\left(\mathrm{mg} \mathrm{kg}^{-1}\right)$ & Humin $\mathrm{N}\left(\mathrm{mg} \mathrm{kg}^{-1}\right)$ \\
\hline $1 / 2 \mathrm{~N}+\mathrm{PK}$ & 1469.2 & 840.5 & 303.4 & 325.3 \\
\hline NPK & 1487.0 & 865.8 & 303.8 & 317.4 \\
\hline $\mathrm{NPK}+\mathrm{FYM}$ & 1503.5 & 873.6 & 313.6 & 316.3 \\
\hline $1 / 2 \mathrm{~N}+\mathrm{PK}+1 / 2 \mathrm{~N} F Y M$ & 1534.2 & 912.8 & 335.8 & 285.6 \\
\hline NPK+Poultry litter & 1504.3 & 900.3 & 321.4 & 282.6 \\
\hline $1 / 2 \mathrm{~N}+\mathrm{PK}+1 / 2 \mathrm{~N}$ Poultry litter & 1537.4 & 926.5 & 327.4 & 283.5 \\
\hline TNPK+Forest litter & 1505.7 & 899.2 & 318.1 & 288.4 \\
\hline $1 / 2 \mathrm{~N}+\mathrm{PK}+1 / 2 \mathrm{~N}$ Forest litter & 1509.1 & 876.2 & 314.4 & 318.5 \\
\hline $1 / 2 \mathrm{~N}+\mathrm{PK}+$ Azospirillum & 1506.3 & 889.5 & 338.7 & 278.1 \\
\hline $\mathrm{NPK}+\mathrm{FYM}+\mathrm{Zn}$ & 1489.0 & 875.6 & 306.4 & 307.0 \\
\hline Forest litter burned $+1 / 2$ FYM & 1535.8 & 911.3 & 337.1 & 287.4 \\
\hline Forest litter burned $+1 / 2$ FYM & 1485.5 & 863.6 & 303.5 & 318.4 \\
\hline $\mathrm{SEm} \pm$ & 7.15 & 8.27 & 4.82 & 5.22 \\
\hline $\mathrm{CD}(p=0.05)$ & 20.98 & 24.25 & 14.13 & 15.30 \\
\hline
\end{tabular}


The highest fulvic P was recorded in NPK+Poultry litter followed by $1 / 2 \mathrm{~N}+\mathrm{PK}+1 / 2 \mathrm{~N}$ Poultry litter and the lowest was recorded in control. The fulvic P in NPK+FYM, NPK+Poultry litter, $\mathrm{NPK}+\mathrm{FYM}+\mathrm{Zn}$ and $1 / 2 \mathrm{~N}+\mathrm{PK}+1 / 2 \mathrm{~N}$ Poultry litter was significantly higher as compared to NPK. The build up in fulvic $P$ in different treatments over control varied from 5.1 to $24.3 \%$ with an average of $12.8 \%$. The significant build up in fulvic $\mathrm{P}$ in NPK + Poultry litter and $1 / 2 \mathrm{~N}+\mathrm{PK}+1 / 2 \mathrm{~N}$ Poultry litter over NPK 13.1 and $8.6 \%$, respectively. The increase in fulvic $P$ in $\mathrm{NPK}+\mathrm{FYM}$ and $\mathrm{NPK}+\mathrm{FYM}+\mathrm{Zn}$ as compared to NPK was 6.4 and $7.1 \%$, respectively. The fulvic P represented 64.2 to $66.6 \%$ of humus $\mathrm{P}$ with an average of $65.4 \%$.

The humic $\mathrm{P}$ in the soil ranged from 25.0 to $33.6 \mathrm{mg} \mathrm{kg}^{-1}$ with an average of $28.5 \mathrm{mg} \mathrm{kg}^{-1}$ in (Table 3) and showed a significant increase in all the treatments except in $1 / 2 \mathrm{~N}+\mathrm{PK}$, $\mathrm{NPK}+$ Forest litter, $1 / 2 \mathrm{~N}+\mathrm{PK}+$ Azospirillum and Forest litter burned $+1 / 2$ FYM over control. The humic P in NPK + Poultry litter and $1 / 2 \mathrm{~N}+\mathrm{PK}+\frac{1}{2} \mathrm{~N}$ Poultry litter was significantly higher as compared to NPK. The increase in humic P in different treatments over control ranged from 3.2 to $34.4 \%$ with an average of $15.4 \%$. The significant build up in humic $\mathrm{P}$ in $\mathrm{NPK}+$ Poultry litter and $1 / 2 \mathrm{~N}+\mathrm{PK}+1 / 2 \mathrm{~N}$ Poultry litter over NPK was $19.6 \%$ and $12.8 \%$, respectively. The humic P represented 19.7 to $22.1 \%$ of humus $P$ with an average of $20.5 \%$.

The humin $\mathrm{P}$ in soil varied from 17.4 to $21.1 \mathrm{mg} \mathrm{kg}^{-1}$ with an average of $19.6 \mathrm{mg} \mathrm{kg}^{-1}$ (Table 3) and showed a significant decrease in NPK+Poultry litter and NPK $+\mathrm{FYM}+\mathrm{Zn}$ over control. The humin $\mathrm{P}$ in NPK+Forest litter and $1 / 2 \mathrm{~N}+\mathrm{PK}+1 / 2 \mathrm{~N}$ Forest litter was significantly higher than NPK. The increase in humin $\mathrm{P}$ in $\mathrm{NPK}+$ Forest litter and $1 / 2 \mathrm{~N}+\mathrm{PK}+1 / 2 \mathrm{~N}$ Forest litter over NPK was $11.6 \%$. The humin P represented 11.4 to $16.1 \%$ of humus $\mathrm{P}$ with an average of $14.1 \%$.
The variation in fulvic, humic and humin $\mathrm{C}, \mathrm{N}$ and $\mathrm{P}$ content in different nutrient management practices may be ascribed to the variation in the quantity of $\mathrm{C}, \mathrm{N}$ and $\mathrm{P}$ added and the nature of microbial metabolites accumulating in these fractions. The changes in $\mathrm{C}, \mathrm{N}$ and $\mathrm{P}$ in fulvic, humic and humin fractions also pointed out that during microbial decomposition all the fractions of the humus may be synthesized and decomposed simultaneously.

\subsection{C:N:P ratio of soil humus and its fractions}

The C:N:P ratio of soil humus varied from 120.8:10.1:1 to 151.2:10.7:1 with an average of 133.1:10.8:1 and the C:N:P ratio of fulvic acid varied from 87.9:9.1:1 to 116.4:9.8:1 with an average of 98.2:9.8:1 (Table 4). The C:N:P ratio of humic acid in different treatments ranged from 116.1:9.7:1 to 148.0:12.1:1 with an average of 137.5:11.3:1. The C:N:P ratio of humin varied from 265.4:15.1:1 to 327.8:16.0:1 with an average of 290.8:15.4:1 (Table 4). The average C:N:P ratio observed in this investigation compare well with the average $\mathrm{C}: \mathrm{N}: \mathrm{P}$ ratio of 100:10:1 suggested for the soils (Russell, 1973). Lower $\mathrm{C}: \mathrm{N}: \mathrm{P}$ ratio of soil humus means more $\mathrm{N}$ and $\mathrm{P}$ per unit of carbon as compared to wider $\mathrm{C}: \mathrm{N}: \mathrm{P}$ ratio. In all the treatments the $\mathrm{C}: \mathrm{N}: \mathrm{P}$ ratios recorded in fulvic acid were lowest and that of humin was highest among all the fractions of soil humus. Similar observations were made by Stewart et al. (1980), Chauhan and Humtsoe (2005) and Belho and Chauhan (2013). The lower C:N:P ratio of cultivated soil mainly are the results of loss of carbon from the soils under cultivation and also the accumulation of $\mathrm{N}$ and $\mathrm{P}$.

The variation in $\mathrm{C}: \mathrm{N}: \mathrm{P}$ ratio of soil humus as well as its fractions is the result of quantitative changes in the content of $\mathrm{C}, \mathrm{N}$ and $\mathrm{P}$ of soil humus, fulvic and humic acid, and humin under different nutrient management practices. The microbial

\begin{tabular}{|c|c|c|c|c|}
\hline Treatments & Humus $\mathrm{P}\left(\mathrm{mg} \mathrm{kg}^{-1}\right)$ & Fulvic $\mathrm{P}\left(\mathrm{mg} \mathrm{kg}^{-1}\right)$ & Humic P $\left(\mathrm{mg} \mathrm{kg}^{-1}\right)$ & Humin $\mathrm{P}\left(\mathrm{mg} \mathrm{kg}^{-1}\right)$ \\
\hline $1 / 2 \mathrm{~N}+\mathrm{PK}$ & 126.9 & 81.5 & 25.0 & 20.4 \\
\hline NPK & 133.3 & 85.8 & 26.8 & 20.7 \\
\hline $\mathrm{NPK}+\mathrm{FYM}$ & 136.6 & 89.6 & 28.1 & 18.9 \\
\hline $1 / 2 \mathrm{~N}+\mathrm{PK}+1 / 2 \mathrm{~N}$ FYM & 143.2 & 95.3 & 29.4 & 18.5 \\
\hline NPK+Poultry litter & 139.4 & 90.5 & 28.5 & 20.4 \\
\hline $1 / 2 \mathrm{~N}+\mathrm{PK}+1 / 2 \mathrm{~N}$ Poultry litter & 152.3 & 101.3 & 33.6 & 17.4 \\
\hline TNPK+Forest litter & 148.1 & 97.3 & 31.7 & 19.1 \\
\hline $1 / 2 \mathrm{~N}+\mathrm{PK}+1 / 2 \mathrm{~N}$ Forest litter & 139.1 & 90.4 & 27.6 & 21.1 \\
\hline $1 / 2 \mathrm{~N}+\mathrm{PK}+$ Azospirillum & 140.2 & 91.1 & 28.0 & 21.1 \\
\hline $\mathrm{NPK}+\mathrm{FYM}+\mathrm{Zn}$ & 136.2 & 88.5 & 27.2 & 20.5 \\
\hline Forest litter burned $+1 / 2$ FYM & 144.5 & 96.0 & 30.5 & 18.0 \\
\hline Forest litter burned $+1 / 2$ FYM & 130.1 & 85.7 & 25.8 & 18.7 \\
\hline $\mathrm{SEm} \pm$ & 2.19 & 1.76 & 1.01 & 0.69 \\
\hline $\mathrm{CD}(p=0.05)$ & 6.44 & 5.17 & 2.97 & 2.03 \\
\hline
\end{tabular}




\begin{tabular}{lcccc}
\hline \multicolumn{5}{l}{ Table 4: Effect of nutrient management practices on C:N:P ratio of soil humus and its fractions } \\
\hline Treatments & Humus & Fulvic & Humic & Humin \\
\cline { 2 - 5 } $1 / 2 \mathrm{~N}+\mathrm{PK}$ & $137.1: 11.6: 1$ & $100.6: 10.3: 1$ & $148.0: 12.1: 1$ & $269.6: 15.9: 1$ \\
$\mathrm{NPK}$ & $132.8: 11.2: 1$ & $97.7: 10.1: 1$ & $141.8: 11.3: 1$ & $265.7: 15.3: 1$ \\
$\mathrm{NPK}+\mathrm{FYM}$ & $130.3: 11.0: 1$ & $94.9: 9.8: 1$ & $135.2: 11.2: 1$ & $291.0: 16.7: 1$ \\
$1 / 2 \mathrm{~N}+\mathrm{PK}+1 / 2 \mathrm{~N}$ FYM & $134.8: 10.7: 1$ & $98.6: 9.6: 1$ & $139.5: 11.4: 1$ & $313.5: 15.4: 1$ \\
NPK+Poultry litter & $134.1: 10.8: 1$ & $99.4: 9.9: 1$ & $140.4: 11.3: 1$ & $279.4: 13.9: 1$ \\
$1 / 2 \mathrm{~N}+\mathrm{PK}+1 / 2 \mathrm{~N}$ Poultry litter & $120.8: 10.1: 1$ & $87.9: 9.1: 1$ & $116.1: 9.7: 1$ & $321.8: 16.3: 1$ \\
TNPK+Forest litter & $122.9: 10.2: 1$ & $90.4: 9.2: 1$ & $119.9: 10.0: 1$ & $293.2: 15.1: 1$ \\
$1 / 2 \mathrm{~N}+\mathrm{PK}+1 / 2 \mathrm{~N}$ Forest litter & $133.7: 10.8: 1$ & $101.8: 9.7: 1$ & $137.7: 11.4: 1$ & $265.4: 15.1: 1$ \\
$1 / 2 \mathrm{~N}+\mathrm{PK}+$ Azospirillum & $151.2: 10.7: 1$ & $116.4: 9.8: 1$ & $157.1: 12.1: 1$ & $293.8: 13.2: 1$ \\
NPK+FYM+Zn & $130.0: 10.9: 1$ & $96.0: 9.9: 1$ & $136.0: 11.3: 1$ & $268.3: 15.0: 1$ \\
Forest litter burned+1/2 FYM & $134.3: 10.6: 1$ & $97.9: 9.5: 1$ & $134.4: 11.7: 1$ & $327.8: 16.0: 1$ \\
Forest litter burned+1/2 FYM & $135.3: 11.4: 1$ & $96.8: 10.1: 1$ & $143.4: 11.8: 1$ & $299.5: 17.0: 1$ \\
\cline { 2 - 4 }
\end{tabular}

population decomposing the residue would use $\mathrm{N}$ and $\mathrm{P}$ to build new protoplasm and these are obtained either from the residues themselves or from other sources added or present in soil. The quantitative and qualitative variations recorded in different treatments are treatment specific and are expected to have a bearing on the size of soil humus $\mathrm{N}$ and $\mathrm{P}$ pool. Large size humus $\mathrm{N}$ and $\mathrm{P}$ pool obviously means availability of $\mathrm{N}$ and $\mathrm{P}$ to plants on mineralization over a long period of time. This would have a favourable bearing on soil fertility status and its conservation. These variations are influenced by the relative amount of $\mathrm{N}$ and $\mathrm{P}$ present in the organic residues added and may have considerable effect on the status of $\mathrm{N}$ and $\mathrm{P}$ in the soil. The variation in $\mathrm{C}: \mathrm{N}: \mathrm{P}$ ratio among treatments suggested that different amount of organic $\mathrm{C}, \mathrm{N}$ and $\mathrm{P}$ had accumulated in soil. These were influenced by the content of these elements in organic sources as well as their input. The implication of this is that the relative amount of $\mathrm{C}, \mathrm{N}$ and $\mathrm{P}$ in organic sources would have considerable impact on the $\mathrm{N}$ and $\mathrm{P}$ status of the soil. The average C:N:P ratio of fulvic, humic and humin fractions were found to be 98.1:9.9:1, 138.0:11.4:1 and 281.8:15.0:1, respectively. Chauhan and Humtsoe (2005) also reported 77.3:9.9:1, 123.9:13.3:1 and 254.6:14.0:1 as average C:N:P ratio of fulvic, humic and humin fractions, respectively. An in depth analysis of average C:N:P ratios established that 10 units of $\mathrm{N}$ in fulvic, humic and humin fractions on an average, accumulated with 99.1, 121.1 and 187.9 units of $\mathrm{C}$, respectively. One unit of $\mathrm{P}$ in these fractions on an average, accumulated with $98.1,138.0$ and 281.8 units of $\mathrm{C}$, respectively. The data led to conclude that under different nutrient management practices, fulvic fraction was the largest repository of $\mathrm{C}, \mathrm{N}$ and $\mathrm{P}$ in soil.

\section{Conclusion}

The data led to conclude that large portion of humus $\mathrm{N}$ and $\mathrm{P}$ accumulated in fulvic fraction followed by humic and humin fractions. The fact that fulvic $\mathrm{N}$ and humic $\mathrm{N}$ increased in all the treatments where as humin $\mathrm{N}$ decreased suggested that the mineralization of humin $\mathrm{N}$ exceeded its synthesis. This however, was not true in case of humin $\mathrm{P}$ that showed variable trends in different treatments. The evidences pointed out that the amount of $\mathrm{C}, \mathrm{N}$, and $\mathrm{P}$ accumulating in soils were influenced by the nutrient management practices.

\section{References}

Anderson, D.W., Schoenau, J.J., 1993. Soil humus fractions. In: Martin R. Carter (Ed.), Soil Sampling and Methods of Analysis. Lewis Publishers 391-396.

Belho, K., Chauhan, B.S., 2013. Effect of nutrient management practices on the content and quality of soil humus in terraced land under continuous cultivation after a decade. Environtment and Ecology 31, 1830-1840.

Chauhan, B.S., Humtsoe, M., 2005. Effect of nutrient management practices and cultivation on the content and composition of soil humus in disturbed soil ecosystem after decade. Environment and Ecology 23, 593-602.

Chopra, S.L., Kanwar, J.S., 1991. Analytical Agricultural Chemistry ( $4^{\text {th }}$ Edn.). Kalyani Publishers, New Delhi.

Gathala, M.K., Kanthaliya, P.C., Verma, Arvind., Chahar, M.S., 2007. Effect of integrated nutrient management on soil properties and humus fractions in the long-term fertilizer experiments. Journal of the Indian Society of Soil Science 55, 360-363.

Gomez, K.A., Gomez, A.A., 1984. Statistical Procedures for Agricultural Research (2 $2^{\text {nd }}$ Edn.). John Wiley\&Sons, INC., UK, 20.

Jackson, M.L., 1973. Soil Chemical Analysis. Prentice Hall of India Private Limited, New Delhi., India.

Laxminarayana, K., Patiram, 2006. Effect of integrated use of inorganic, biological and organic manures on rice productivity and soil fertility in ultisols of Mizoram. Journal 
of the Indian Society of Soil Science 54, 213-220.

Russell, E.W., 1973. Soil condition and plant growth. Longman and Co., London.

Sihag, D., Singh, J.P., Mehla, D.S., Bhardwaj, K.K., 2005. Effect of integrated use of inorganic fertilizers and organic materials on the distribution of different forms of nitrogen and phosphorous in soil. Journal of the Indian Society of Soil Science 53, 80-84.

Stewart, J.W.B., Hedley, M.J., Chauhan, B.S., 1980. The immobilization, mineralization and redistribution of phosphorus in soil. In: Harapia, J.T. (Ed.). Proceedings of Western Canada Phosphate Symp., Calgary, Alberta.

Yaduvanshi, N.P.S., Sharma, D.R., Swarup, A., 2013. Impact of integrated nutrient management on soil properties and yield of rice and wheat in a long-term experiment on a reclaimed sodic soil. Journal of the Indian Society of Soil Science 61, 188-194. 